\title{
KARAKTERISTIK JIWA KEHIDUPAN MASYARAKAT (VOLKSGEIST) INDONESIA TERHADAP OMNIBUS LAW
}

\author{
Oleh:
}

Fiska Maulidian Nugroho

fiska.fh@unej.ac.id

\begin{abstract}
Abstrak
Omnibus Law merupakan teknik/metode penyederhanaan hukum (simplikasi hukum) yang dituangkan pada terciptanya Undang-Undang Cipta Kerja. Sebuah momentum yang akan dikaji menggunakan aliran filsafat sejarah hukum yang dipelopori oleh beberapa ahli hukum terdahulu, ikon pada saat itu adalah F.K. von Savigny. Ia menolak Mazhab Hukum Alam dan Positivisme Hukum untuk Unifikasi/Kodifikasi Hukum Jerman pada waktu itu, ia lebih memilih Kodifikasi yang dibentuk menggunakan karakter jiwa bangsa (Volksgeist). Oleh karena itu, pendekatan yang digunakan untuk menganalisis UU Cipta Kerja yang menggunakan teknik Omnibus Law dirasakan bertentangan dengan karakteristik pembentukan hukum berdasarkan Aliran/Mazhab Sejarah Hukum (Historical Jurisprudence) ini. Metode penelitian ini menggunakan Metode Penelitian Hukum Normatif dan Yuridis Sosiologis.

Kata Kunci : Omnibus Law, Filsafat Sejarah Hukum, Pluralisme Hukum

\section{PENDAHULUAN}

Beranjak dari lahirnya Rancangan Undang-Undang Cipta Kerja atau UU dengan metode Omnibus Law yang kemudian di respon oleh publik melalui upaya demonstrasi bahkan tantangan debat terhadap menteri serta ancaman mogok kerja sebagai bentuk penolakan

Undang-Undang Cipta Kerja. Disampaikan pula oleh Mahfud MD yang berkedudukan sebagai Menteri Koordinasi Politik Hukum dan Keamanan bahwa Omnibus Law ini dengan resmi mencabut beberapa pasal, merevisi sebanyak 79 Undang-undang yang terdiri dari 1.244 (seribu dua ratus empat puluh empat) Pasal, dimana Pasal yang terevisi akan memangkas hal yang
\end{abstract}


selama ini menghambat masuknya investasi dalam negeri. Namun demikian, beberapa bentuk respon masyarakat terkait berlakunya UndangUndang ini masih beralasan, diantaranya adalah pertanyaan mengapa di masa pandemi yang masih belum berakhir ini ternyata masih juga diselipi rencana pengesahan UU Cipta Kerja, padahal bisa saja akan berpotensi nir akuntabilitas serta partisipasif terhadap penyusunannnya. Namun pada akhirnya, pada hari Senin tertanggal 2 November 2020, dimana menjadi tiga hari lebih cepat dari batas waktu maksimal tanda tangan Presiden.

Kritik dan respon kegamangan atas keberlakuan UU Cipta Kerja (Omnibus Law) pada saat itu sedemikian wajar dan sepatutnya haruslah ada, karena hukum tumbuh bersama pertumbuhan bangsa (rakyat) dan menjadi kuat bersama dengan kekuatan bangsa, serta akan mati jika suatu bangsa kehilangan kebangsaannya. Kekuatan untuk mempertahankan bangsa (rakyat) tersebut harus ada, keberadaannya diperlukan suatu organisasi yang memiliki kesadaran dan kekuatan untuk mempertahankannya, dalam hal ini adalah negara. Organ berupa Negara tentu dipandang bukan lagi hanya sebagai ancaman terhadap historis organisme masyarakatnya ketika mewujudkan produk legislasi, namun malah menjadi representasi yang otentik (authentic representative).

$$
\text { Perkembangan hukum }
$$

berdasarkan sistem hukum di Indonesia tidak begitu saja muncul tanpa balutan sejarah dan sejarah perpolitikan di kehidupan berbangsa dan bernegara, sebagaimana disampaikan oleh Mahfud MD yang mengutip Daniel Lev, untuk memahami sistem hukum di tengahtengah transformasi politik harus diamati dari bawah dan dilihat peran sosial politik apa yang diberikan orang kepadanya. Karena lebih kuatnya konsentrasi energi politik, maka menjadi beralasan adanya konstatasi bahwa kerapkali otonomi hukum di Indonesia ini diintervensi oleh politik, bukan hanya dalam proses pembuatannya, tetapi juga dalam implementasinya. Diantara dinamika politik tersebut, terdapat kebiasaan perihal teknik pembentukan peraturan perundang-undangan di Indonesia diantaranya dikenal dengan konsep Undang-Undang Kodifikasi. Pengejahwantahan UU dengan metode Omnibus Law itu sendiri menimbulkan 
argumentasi untuk mendeskripsikan apa itu Omnibus Law, meskipun banyak penolakan pada proses pembentukannya, namun sebagai teknik penggabungan atau pengumpulan ketentuan dari banyak UU, tentu UU ini juga memiliki banyak manfaat keunggulan dan beberapa kelemahan.

Disampaikan oleh Louis Massicotte yang dikutip Bayu Dwi Anggono bahwa dengan digunakan teknik Omnibus law akan menghemat waktu dan mempersingkat proses legislasi, karena tidak perlu melakukan perubahan terhadap banyak UU yang akan diubah, tetapi cukup melalui satu rancangan UU yang berisikan banyak materi perubahan dari berbagai UU. Dengan hanya melalui satu UU yang berisikan banyak materi perubahan dari berbagai UU, maka dapat terhindar dari lamanya perdebatan anggota legislatif pada masing-masing UU jika perubahan dilakukan dengan cara biasa. Selain itu, hubungan partai oposisi (minoritas) dan mayoritas di parlemen yang biasanya berdasarkan prinsip menang dan kalah dalam pembahasan rancangan $\mathrm{UU}$, karena dengan Omnibus Law sama-sama menjadi memiliki kesempatan. Mengingat materi/substansi Omnibus
Law sangat banyak, maka membuat penolakan terhadap keseluruhan isi suatu UU oleh partai oposisi dapat terhindarkan karena partai oposisi menjadi memiliki opsi menolak suatu substansi, tetapi di sisi lain menyetujui substansi lainnya.

Pandangan atas Volkgeist mendasari bahwa hukum didasarkan pada karakter kebangsaan dan jiwa kebangsaan bangsa yang bersangkutan, setidaknya tulisan ini nantinya sedikit menjawab mengapa jiwa bangsa yang hidup di masyarakat penting untuk dihadirkan pada setiap peraturan perundang-undangan yang pada hal ini telah berlaku. Produk hukum yakni UU Cipta Kerja (Omnibus Law) seharusnya merupakan cerminan bahwa eksistensi sebagai negara hukum tentunya Indonesia dalam merumuskan setiap instrumen hukum, harus berpedoman kepada Pancasila sebagai Volkgeist yaitu sebagai sebuah sistem nilai dalam roda kehidupan berbangsa dan bernegara yang digali sesuai cita-cita, kebudayaan dan perjalanan hidup bangsa Indonesia.

Berdasarkan perihal latar belakang diatas, maka seyogyanya dapat dirumuskan rumusan masalah antara lain, apakah metode Omnibus Law yang 
melandasi terbentuknya UU Cipta Kerja telah mencerminkan Jiwa Bangsa (Volksgeist), dan yang kedua, bagaimanakah peluang dan tantangan metode Omnibus Law ketika dihadapkan pada karakter pluralistik bangsa Indonesia?

\section{METODE PENELITIAN}

Penelitian hukum telah dikenal adanya dua pendekatan yaitu pendekatan secara normatif maupun secara yuridis sosiologis, dimana pendekatan yang pertama tersebut merupakan metode yang digunakan untuk mencari jawaban terhadap permasalahan dan tujuan penelitian berdasarkan kerangka teori hukum normatif. Teori yang nantinya digunakan ini digunakan untuk menelaah data sehingga dikatakan sebagai teori hukum doktrinal, seperti kaidah-kaidah hukum, asas-asas hukum, pengertian-pengertian hukum dan sebagainya. Begitu juga penelitian ini menggunakan pendekatan yang kedua yakni yuridis sosiologis yang bercirikan pada pencarian jawaban terhadap permasalhan dan tujuan penelitian dengan menggunakan teori hukum empiris-sosiologis hukum. Pada akhirnya, penulisan ini menggunakan pendekatan yuridis normatif melalui pendekatan perundang-undangan maupun konsep dan mengkaji dokumen dari berbagai data sekunder seperti peraturan perundang-undangan dan teori hukum.

\section{HASIL DAN PEMBAHASAN}

\section{AUTOKRITIK \\ TERHADAP \\ OMNIBUS LAW SEBAGAI BAGIAN \\ DARI PENGEJAWANTAHAN \\ JIWA RAKYAT (VOLKSGEIST) INDONESIA}

Pemikiran tentang Volksgeist tidak terlepas dari aliran dalam filsafat hukum historis, thesis utama dalam aliran pemikiran filsafat hukum historis adalah bahwa studi mengenai sistem hukum yang ada memerlukan pemahaman mengenai akar sejarah dan pemahaman tentang pola-pola evolusi dari sistem hukum tersebut. Pemikiran von Savigny ini membawa pada kesadaran akan waktu dan konteks dari keberadaan hukum, hukum seperti bahasa dan seni yang berwujud budaya rakyat dalam memaknai hidupnya. Hukum bukanlah permainan kelompok elitis yang dapat 
memunculkan pemandangan imaginer atau seolah-olah rakyat dalam pulasan kehendak masyarakat berlabel mayoritas. Hukum adalah kesadaran rakyat akan waktu dan tempatnya berada. Hukum adalah wujud komunikasi jujur dalam rakyat dalam bernegara. Bahkan dalam semesta pemikiran von Savigny, konteks Rakyat (People atau Volk) dan Legislasi dalam fungsinya, hukum yang dihasilkan, serta peranannya pada ilmu hukum menjadi tiga dari lima kunci pemikiran Savigny.

Pemikiran Mazhab Sejarah ini tidak begitu saja muncul, pemikiran Savigny terbentuk oleh gagasan Ahli hukum Jerman pada abad 18 yakni Edmund Burke (1729-1797) dimana Burke menggunakan pndekatan yg konservatif terhadap perubahan sejarah di Prancis dan menekankan pentingnya keberlanjutan historis dan meyakini bahwa masyarakat tidak akan bisa mewariskan sesuatu kepada generasinya apabila tidak pernah menoleh kepada jejak historis leluhurnya. Begitu pula pandangan Johann Gottfried von Herder (1744-1803) yang menekankan pentingnya tradisi kultural (budaya bangsa). Bahkan, Gustav Hugo dari Grottingen menegaskan dengan unik antara hukum dan kehidupan setiap masyarakat tertentu merusak tesis hukum kodrat dari sudut pandang sejarah dan pengalaman manusia. Ia menentang gagasan hukum kodrat tentang hukum yg universal, ia menekankan bahwa hukum harus mencerminkan kebutuhan dan karakter unik masyarakat setiap bangsa. Jika di Inggris terdapat Sr. Henry S. Maine (1822-1888), ia memandang bahwa kebebasan bersepakat sebagai semacam prestasi puncak dari perkembangan hukum. Begitu pula pada Bangsa Indonesia, tidak dapat terlepas dari pemikiran tentang Volksgeit, pada masa kolonial, pandangan hukum dianut oleh Van Vollenhoven, Ter Harr, Holeman, dan lain-lain, sehingga huum adat diberlakukan sebagai hukum yang berlaku bagi golongan Indonesia asli di samping berlakunya hukum perdata Barat bagi golongan Eropa dan yang dipersamakan yang sudah terkodifikasi di dalam Kitab Undang-Undang Hukum Perdata (B.W).

Rakyat dan proses legislasi tidak akan terpisahkan sampai kapanpun, terutama dalam sistem hukum bernegara di Indonesia yang memiliki karakteristik demokrasi yang partisipatif, jika merujuk pada aliran pemikiran proses 
pembuatan kebijakan dalam perspektif demokrasi, maka Indonesia hanya menempatkan ide demokrasi hanya sebagai mesin politik dimana Pancasila adalah pandangan hidup suatu bangsa. Aliran pemikiran demokratis ini terdapat dua aliran, aliran pertama adalah aliran teori demokrasi partisipatif yakni memandang bahwa partisipasi publik adalah suatu hal yang sifatnya aktif dan dikembangkan dalam suatu suasana yang berkelanjutan dengan fokus kekuasaan pengambilan keputusan berada pada publik, sedangkan aliran yang kedua adalah aliran teori demokrasi elit, dimana lebih menekankan kepercayaan tentang adanya peran publik secara terbatas atau pasif dengan fokus kekuasaan pembuatan kebijakan berada pada birokrasi atau elit teknokrat yang dipandang sebagai aktor yang paling mampu dalam melakukan pengambilan keputsan kebijakan.

Konteks partisipasi publik seyogyanya merupakan jaminan yang tidak bisa ditawar, perihal demikian menjadi salah satu syarat dapat diadopsinya teknik/metode Omnibus Law di Indonesia, diantaranya:
1. Adanya pemenuhan asas keterbukaan, kehati-hatian, dan partisipasi masyarakat,

2. Diperlukan sosialisasi yang luas, terutama bagi pejabat dan pihak yang terkait substansi RUU-nya, kalangan profesi hukum, dan akademisi;

3. Pembahasan di DPR yang transparan dengan memperhatikan masukan dari pihak-pihak yang mempunyai hubungan dengan RUU, dan tidak tergesa-gesa pembahasannya;

4. Mempertimbangkan jangka waktu yang efektif berlakunya UU tersebut;

\section{Mempertimbangkan} keberlakuan UU yang terdampak (existing).

Entitas kebangsaan dicerminkan melalui individu-individu (volks) sebagai kesatuan alamiah dan kesatuan ini berjalan dari generasi ke generasi, bahkan kesadaran rakyat menciptakan dan menumbuhkan hukum positif, mengapa demikian, karena hukum positif tentu memiliki konteks tempat dan waktu keberlakuan tertentu, entah 
hukum positif tersebut tercatat secara tertulis dengan otoritas formal yang mengundangkannya, namun hukum positif tersebut tidak lain juga berada pula pada pengakuan dari masyarakat. Bukankah hukum yang paling ideal adalah hukum yang berasal dari hubungan unik antara hukum dan kehidupan setiap masyarakat, senyampang berasalnya adalah dari sudut pandang sejarah serta pengalaman manusia.

Manusia tidak hanya sebagai individu saja, namun manusia juga sebagai anggota atau warga dari suatu olektivitas dan juga untuk tujuan diri sendiri. Maka, pengendalian hubungan antara manusia atau masyarakat atas masalah-masalah sosial-ekonomi atau hajat hidup mereka adalah tugas negara. Negara wajib untuk mengintervensi permasalahan tersebut, yaitu menjamin terciptanya kesejahteraan bersama dalam masyarakat. Negara dalam hal ini dipandang sebagai agency of service, sehingga konsep negara kesejahteraan/kemakmuran (Welfare State) adalah pilihan yang paling ideal untuk memadukan perjalanan estetika ramantisme hukum, yakni pada hakikatnya telah meratakan jalan bagi

sebuah hubungan baru antara penguasa dan warga negara, yang oleh orangorang hidup dibawah kekuasaan Negara sebagai entitas dari kedaulatan rakyat merasa lebih layak dan adil.

Partisipasi rakyat adalah esensi dari sistem demokrasi, oleh karena itu, negara hukum harus ditopang dengan sistem demokrasi karena terdapat korelasi yang jelas antara negara hukum yang bertumpu pada konstitusi, dengan kedaulatan rakyat yang dijalankan melalui sistem demokrasi. Maka, kedaulatan rakyat yang diagungagungkan di Bangsa Indonesia terletak pada implementasi perubahan perilaku, dan jika diletakkan dalam konteks politik, maka bermuara pada kedaulatan dan kemakmuran rakyat sebagaimana tertuang terlebih dahulu pada UndangUndang Dasar Negara Republik Indonesia Tahun 1945 (UUD 1945), serta harus sesuai dengan semangat yang terdapat dalam sila ke-4, yang berpijak pada "kebijaksanaan dalam permusyarawan perwakilan".

Penjabaran Pancasila yang
tertuang dalam sila-silanya pada
dasarnya memuat eksistensi volksgeist
dimana bangsa Indonesia dalam praktek
ketatanegaraan $\quad$ juga


menggunakan kebiasan-kebiasan ketatanegaraan yang tidak tercantum di dalam undang-undang yang tertulis atau yang biasa di kenal dengan konvensi, selain itu dalam penegakan hukum pun seringkali penyelesaian sengketa hukum yang terjadi di masyarakat bangsa ini menggunakan nilai-nilai hukum yang berkembang dan hidup di dalam masyarakat (living law) semisal hukum adat.

Di sisi lain, fungsi keberadaan Pancasila adalah membangun kesadaran moral dalam berbangsa dan bernegara baik sebagai kultur (masyarakat), struktur (para penegak hukum) maupun sebagai hukum dan undang-undang (substansi) sehingga tidak ada ruang sedikitpun dalam bangsa ini tidak tersentuh dengan pancasila yang keberadaanya sebagai spirit dan jiwa bangsa (volksgeist).

Penelusuran terhadap aspek proses disahkannya UU Cipta Kerja telah diketemukan seakan-akan tertutupnya metoda partisipasi yang dituangkan dalam Pasal 96 Undang-Undang No. 12 Tahun 2011 yang mengatur bahwa masyarakat (orang perseorangan atau kelompok orang yang mempunyai kepentingan atas substansi rancangan peraturan perundang-undangan) berhak memberikan masukan secara lisan dan/atau tertulis itu dapat dilakukan melalui rapat dengar pendapat umum, kunjungan kerja, sosialisasi, dan/atau seminar, lokakarya, dan/atau diskusi. Masyarakat dalam penjelasan pasal tersebut disebutkan bahwa termasuk kelompok orang antara lain kelompok/organisasi masyarakat, kelompok profesi, lembaga swadaya masyarakat, dan masyarakat adat.

Formalitas pembentukan UU sebenarnya menjadi syarat penting bagi legitimasi hukum. Kekuasaan itu pada dasarnya harus dibatasi. Dan dalam melaksanakan kekuasaan itu, harus ada pembatasan-pembatasan dalam konteks formal agar kekuasaan tersebut tidak dibuat secara serampangan. Formalitas itu menjadi kontrol terhadap keserampangan dan kesewenangan itu. Artinya, hukum harus dijaga agar tidak dibuat dengan seenaknya, tetapi harus melalui konsep dan mekanisme yang disepakati. Dalam hal ini, tentu saja UU juga harus melalui konsep itu. Formalitas kaku itu juga sebagai potret penghargaan atas kedaulatan rakyat. Peran dalam bentuk partisipasi, aspirasi dan transparansi menjadi kewajiban yang 
melekat dengan hak-hak warga negara yang akan diatur dalam suatu UU.

Kritik terhadap teknik Omnibus Law ini mengalir deras diantaranya melalui Wahana Lingkungan Hidup Indonesia (WALHI) yang menyatakan pada poin-poin tertentu yakni: (i) Melegitimasi investasi perusak lingkungan, mengabaikan investasi rakyat dan masyarakat adat yang lebih ramah lingkungan dan menyejahterakan. Alasan ini termasuk didalamnya pemerintah tidak pernah menanggap keberadaan investasi masyarakat lokal (masyarakat adat) selama ini. Padahal jika dinominalkan masyarakat adat telah menjalankan investasi triliunan rupiah dalam bentuk ekosistem yang sehat dan berkelanjutan (hutan yang lebat dan subur, sungai yang bersih, dan pantai dan lautan yang biru dan jernih). Namun celakanya, dengan adanya, apa yang telah diinvestasikan masyarakat adat dihancurkan bahkan dibagi-bagi melalui konsesi-konsesi ekstraktif yang hanya menguntungkan segelintir investor hitam yang dilindungi kekuasaan negara; (ii) Penyusunan UU tersebut cacat prosedur karena dilakukan secara tertutup, tanpa partisipasi masyarakat sipil, dan mendaur ulang pasal inkonstitusional. Alasan ini didasari pada cacat prosedur pada penyusunan yang nir-partisipasi rakyat, adanya pasal pengaturan sentralisasi pada Presiden dalam rangka pembatalan Perda; (iii) Satgas Omnibus law bersifat elitis dan tidak mengakomodasi elemen masyarakat yang terdampak keberadaan seperangkat UU Omnibus law, kritik tersebut muncul akibat konten UU hanya akan mengakomodasi kepentingan pengusaha nirkepentingan masyarakat lainnya, bahkan sangat dimungkinkan bertentangan dengan kepentingan masyarakat secara umum. Lebih parah lagi, ada beberapa anggota Tim Satgas ini yang terindikasi terseret dalam beberapa kasus korupsi (Kasus Bank Century, Impor Garam, Impor Bawang Putih, dsb). Tentunya hal ini akan sangat berisiko terhadap agenda pemberantasan korupsi mengingat UU ini akan memuat beberapa ketentuan yang akan berhubungan dengan penghapusan sanksi pidana bagi korporasi. (iv) Sentralisme kewenangan yaitu kebijakan ditarik ke pemerintah pusat yang mencederai 
semangat reformasi. (v) Celah korupsi melebar akibat mekanisme pengawasan yang dipersempit dan penghilangan hak gugat oleh rakyat. (vi) Perampasan dan penghancuran ruang hidup rakyat Atas nama kepentingan pembangunan dan ekonomi. (vii) Percepatan krisis lingkungan hidup akibat investasi yang meningkatkan

pencemaran lingkungan, bencana ekologis (manmade disaster), dan kerusakan lingkungan. (viii) Menerapkan perbudakan modern lewat sistem fleksibilitas tenaga kerja berupa legalisasi upah di bawah standar minimum, upah per jam, dan perluasan kerja kontrak-outsourcing. (ix) Potensi PHK massal dan memburuknya kondisi kerja. (x) Membuat orientasi sistem pendidikan untuk menciptakan tenaga kerja murah. (xi) Memiskinkan petani, nelayan, masyarakat adat, perempuan dan anak, difabel, dan kelompok minoritas keyakinan, gender dan seksual. (xii) Kriminalisasi, represi, dan kekerasan negara terhadap rakyat, sementara negara memberikan kekebalan dan keistimewaan hukum kepada para pengusaha.
Dari nilai-nilai yang semestinya ada pada hukum yang berkembang dan hidup di dalam masyarakat, meskipun sejatinya tujuan dari metode Omnibus Law tetap pada terciptanya UU Cipta Kerja, maka proses legislasinya mau tidak mau harus sejalan dengan semangat dan nilai-nilai Pancasila, mengapa demikian, karena memang tujuan awal UU Cipta Kerja merupakan payung hukum yang memberikan peluang investasi guna keberlangsungan pembangunan yang berkaitan langsung dengan kehidupan masyarakat Indonesia, sehingga sangat diharapkan dapat menurunkan angka kemiskinan dengan terciptanya peluang menciptakan lapangan kerja. Namun, akankah proses legislasi ini pada akhirnya dapat diartikan secara total mengaktualisasikan artian tentang volksgeist untuk menjadikan UU Cipta Kerja sebagai hukum positif. Ini akan bertetangan dan berhadap-hadapan dengan semangat kebangsaan apabila ketika hukum (UU) tidak lagi mendapat dukungan dari rakyat. Dukungan dapat diartikan sebagai ketersentuhan, keberpijakan atau keberpihakan, karena ia (hukum/UU) tidak lagi menjadi hukum positif yang menjadi cerminan 
dari kesadaran rakyat, hukum tersebut menjadi monopoli bagi kelompok tertentu saja yang sungguh elitis, dan menjadi alat legitimasi mereka, sehingga makna rakyat atau volksgeist tidak bermakna lagi dan memudar, serta hukum hilang bersamaan dengan hilangnya konteks keberadaannya. Metode yang partisiptif tersebut tentunya harus kembali lagi digali, akankah ikon "volks" sebagai bangsa atau rakyat merupakan bangsa atau rakyat yang sebenar-benarnya, janganjangan hanya simbol yang pada akhirnya berhilir pada kepentingan politik dan kekuasaan.

\section{OMNIBUS LAW DIHADAPKAN PADA KARAKTER PLURALISME HUKUM BANGSA INDONESIA}

Pandangan Volksgeist yang pada hakikatnya menolak pandanganpandangan terhadap hukum dan pembentukan hukum sebelumnya yakni hukum alam dan positivisme hukum. Bahkan, pandangan atas pemikiran tersebut menegaskan bahwa hukum "tidak ada dalam dirinya sendiri", sebab esensinya adalah "kehidupan manusia" yang tidak dilihat dari aspek tertentu.
Hukum bukan produk yang dibentuk dengan alasan tertentu dan lalu ditetapkan dalam Undang-Undang. Hukum bahkan bukan sesuatu yang ada, tetapi suatu kesadaran yang hidup dan berubah yang selamanya berada dalam proses menjadi. Dalam arti penting, hukum, sebagaimana dikatakan oleh Roger Berkowitz oleh karenanya dapat dikatakan tidak ada. Kalaupun ada, hukum pada awalnya berada dalam kesatuannya dengan bahasa, moral, dan ketertiban sebagai emanasi atau pancaran kepercayaan rakyat. Ini sebabnya, hubungan organik antara manusia dan hukum ada dalam konsep budaya yang lebih universal, yang dibangun berdasarkan bahasa, moral, dan ketertiban. Hukum sebagai bagian dari budaya digambarkan sebagai fenomena kesatuan; dan hanya dengan itu bisa dipahami. Dengan begitu, hukum merupakan bagian saja di antara aspek integratif budaya, dan karenanya juga dapat dikatakan, sebagaimana Augusto Zimmermann, hukum merupakan produk konvensi budaya.

Pluralisme hukum didasarkan pada adanya beberapa faktor, yakni faktor historis bangsa Indonesia yang memiliki keragaman suku, bahasa, dan ras. 
Terdapat hal yang menarik, UU Cipta Kerja ini kita terbiasa menyebutnya dengan sebutan metode penyederhanaan regulasi (simplikasi), harmonisasi regulasi, unifikasi aturan, atau kodifikasi. Namun pada dasarnya, metode ini dilakukan dengan mengukur relevansi suatu regulasi dengan kriteria yang bersifat mendasar. Kriteria tersebut terkait dengan aspek legalitas, aspek kebutuhan, dan aspek kemudahan prosedur (friendly). Aspek legalitas ditujukan untuk meninjau apakah suatu regulasi dalam pengaturannya tidak ditemui adanya potensi multitafsir dalam perumusan normanya ataupun potensi konflik, duplikasi, inkonsistensi atau bahkan tidak operasional. Aspek kebutuhan ditujukan untuk meninjau apakah suatu regulasi mempunyai kejelasan tujuan dan didasarkan oleh kebutuhan yang mendasar bagi masyarakat maupun bagi penyelenggara negara. Sedangkan aspek kemudahan prosedur (friendly) ditujukan untuk meninjau apakah sebuah regulasi mudah untuk dipahami dan dipatuhi serta tidak memberikan beban yang berlebihan kepada pihak-pihak yang terkena dampak langsung. Dengan kata lain, tujuan regulasi dapat dicapai tanpa memberikan beban yang tidak perlu bagi kelompok yang terkena dampak pengaturan regulasi tersebut. Perihal ketiga aspek tersebut seakan menapakkan bahwa banyaknya regulasi belum tentu memudahkan kita untuk berinovasi, malah semakin banyak menimbulkan konflik. Salah satu konflik atau persoalan dua regulasi peraturan perundang-undangan adalah UndangUndang No. 4 Tahun 2009 tentang Pertambangan Mineral dan Batubara. Inkonsistensi muncul karena tidak menjadikan Undang-Undang No. 5 Tahun 1960 Pokok Agraria sebagai sumber hukum. Orientasi UU Minerba lebih condong kepada produksi bukan konservasi. Hal ini menguntungkan pihak swasta dan pengelola dan dapat merugikan negara. Polemik UU Minerba antara rezim pemerintah juga menguat karena perbedaan kepentingan rezim. Sejak keberadaan UU Minerba pemerintah dinilai kalah dengan kepentingan perusahaan karena banyak perusahaan yang tidak memenuhi kewajibannya serta cenderung mengabaikan kewajibannya kepada pemerintah. UU Nomor 4 Tahun 2009 juga tidak tegas mengatur mengenai ganti rugi bagi pemegang hak atas tanah 
yang tanahnya diambil untuk kepentingan kegiatan pertambangan.

Peluang dan tantangan perihal metode Omnibus sekurang-kurangnya terdapat empat manfaat, yakni: (i) mempersingkat pelaksanaan proses legislasi; (2) mencegah kebuntuan dalam pembahasan RUU di parlemen; (iii) efesiensi biaya proses legislasi; dan (iv) harmonisasi pengaturan akan terjaga. Peluangnya adalah terjadinya transplantasi hukum sebagai proses ketika hukum dan lembaga hukum dikembangkan dalam satu negara, kemudian diadopsi oleh yang lain maka hal demikian akan sangat tergantung pada gagasan dan kekuatan yang ada dalam hukum itu sendiri. Begitu pula dengan tantangannya, yakni: (i) permasalahan regulasi Indonesia kompleks; (ii) tiap-tiap UU yang ketentuannya diubah oleh Omnibus Law telah memiliki landasan filosofis; (iii) prinsip supremasi konstitusi meletakkan batas-batas kewenangan mengatur tiap jenis Pengaturan Perundang-undangan; (iv) ketidakpastian hukum akibat dominasi ego sektoral antarpenyelenggara negara; (v) parameter menemukan kapan suatu materi harus dengan Omnibus Law dan kapan dengan UU biasa; (vi) partisipasi publik dalam pembentukan UU telah dijamin pada semua tahapan pembentukan. Peluang dan tantangan tersebut dibatasi hanya pada permasalahan regulasi Indonesia yang kompleks, terkait dengan organ masyarakat yang tumbuh dan mengakar kuat sebelum pandangan postivisme yang meletakkan dasar pemikirannya pada science. Landasan filosofis yang seyogyanya menjadi pandangan yang berangkat dari pandangan pluralistik dan menuju pada kesejahteraan masyarakat jika telah terbentuknya dan disahkannya Undang-Undang tersebut, dan partisipasi publik sebagai sifat yang mengikat disetiap terciptanya sebuah UndangUndang.

Letak pluralisme sebagai landasan yang setidaknya menjadi kritik atas pandangan yang telah mengakar pada bagaimana pembentukan hukum di Indonesia. Ada ke-khas-an secara magis yang dibuktikan secara sosio-politik mengorganisasikan dirinya ke dalam sebuah kesatuan hukum yang justru tidak didasarkan pada hukum positif negara, melainkan pada hukum adat yang mereka warisi secara tradisional dari nenek moyang mereka. Meskipun 
demikian pandangan atas rakyat (Volks) tentu tidak beranjak dari hukum adalah kenyataan dalam kehidupan masyarakat. Pada prinsipnya hukum dipandang sebagai bagian kebudayaan, yang memberi pedoman bagi warga masyarakat mengenai apa yang boleh dan apa yang tidak (normatif), dan dalam hal apa (kognitif). Oleh karena hukum adalah bagian dari kebudayaan, maka konsepsi normatif dan kognitif tersebut bisa berbeda-beda di setiap kebudayaan, dan bisa berubah di sepanjang waktu. Dalam pemikiran prosedural, hukum dipandang sebagai gejala sosial atau proses sosial, artinya, hukum selalu berada dalam pergerakan (dinamika), karena dipersepsikan, diberi makna dan kategori secara beragam dan berubah sepanjang waktu. Konsep pluralisme hukum ini menjadi bingkai bahwa negara dihadapkan pada keadaan revolusi atau era industri dan investasi, serta dinamika perubahan sistem teknologi informasi. Pandangan pluralisme atas hukum ini menjelaskan bagaimanakah hukum yang beranekaragam secara bersama-sama mengatur suatu perkara, begitu juga pada pandangan ini, dapat diamati bagaimanakah semua aturan-aturan ini secara bersama-sama beroperasi dikehidupan sehari-hari, konteks ini berkaitan pula atas dasar apa orang memilih (kombinasi) aturan hukum tertentu, dan dalam konteks apa ia memilih aturan dan sistem peradilan yang lain. Pada akhirnya, perkembangan bentuk-bentuk hukum baru tidak memberi framing atau label dipebagai negara, yakni hukum negara, hukum adat, atau hukum agama, sehingga disebut sebagai hybird law, dan banyak pengarang lain menyebutnya unnamed law. Dalam hal ini, catatan kritis yang disampaikan oleh Sulistyowati Irianto perihal pengkajian pada suatu rangkaian persitiwa maka berdasarkan hubungan makro (negara) dan mikro (individu) dan hubungan antar waktu, sengketa atau konflik dipandang sebagai kejadian yang biasa dalam kehidupan sosial sehari-hari. Bukan sebagai suatu penyimpangan, kebetulan, atau kondisi yang tidak normal. Oleh karena itu untuk dapat menjelaskannya harus dilakukan dengan cara mengungkapkan konteks dari proses sosial yang diperluas (extended social processes, extended case method) di seputar terjadinya suatu sengketa. Hal tersebut membutuhkan deskripsi mengenai konteks sosial yang total. 
Perihal demikian, Omnibus Law pada kenyataanya bukan karena kondisi yang tidak normal, namun teknik ini merupakan cara mengungkapkan konteks proses perubahan pembentukan hukum yang bertitik taut akan suatu rangkaian peristiwa, yakni era industri dan investasi.

\section{KESIMPULAN}

Bila mengamati perkembangan era industri, investasi dan sumber daya alam, landasan penyederhanaan peraturan (simplikasi) melalui teknik Omnibus Law merupakan momentum yang tepat guna kepentingan negara untuk menyejahterakan masyarakat Indonesia. Namun disisi yang lain, karakteristik bangsa yang menyertakan partisipasi publik dalam pembentukan undangundang sebagai pengejawantahan jiwa rakyat adalah cerminan pembentukan yang tidak dapat dilepaskan dari Bangsa Indonesia. Berkaca dari pluralisme hukum di Indonesia, hukum kebiasaan yang diakui dalam Mazhab Sejarah Hukum mulai sekarang tidak diberikan batasan lagi. Dengan demikian, Omnibus Law merupakan teknik yang tiba-tiba saja terjadi, namun melalui proses yang dikalkulasikan dari berbagai peristiwa sosial.

\section{SARAN}

Meskipun peluang disederhanakannya peraturan ini tetap dibutuhkan yakni Teknik/Metode Omnibus Law seyogyanya tetap memberikan peluang partisipasi publik sebagai kontribusinya dalam pengejawantahan jiwa rakyat, dikarenakan kondisi sejarah secara tegas tidak terlepas dari watak pluralistik pada masyarakatnya.

\section{DAFTAR PUSTAKA}

Aulia MZ, 'Friedrich Carl von Savigny Tentang Hukum: Hukum Sebagai Manifestasi Jiwa Bangsa' (2020) 3

Undang: Jurnal Hukum 201

Azhar M, 'Omnibus Law sebagai Solusi Hiperregulasi Menuju Sonkronisasi Peraturan PerUndang-undangan di Indonesia' (2019) 2 Administrative Law and Governance Journal 170

Bayu Dwi Anggono, Pokok-Pokok Pemikiran Penataan Peraturan Perundang-Undangan Di Indonesia (Kompress 2020) 
'Booklet: Omnibus Law Lapangan Kerja' Kementerian Koordinator Bidang Perekonomian Republik Indonesia

Busroh FF, 'KONSEPTUALISASI OMNIBUS LAW DALAM MENYELESAIKAN

PERMASALAHAN REGULASI PERTANAHAN' (2017) 10 Arena Hukum 227

Cahyadi A, 'HUKUM RAKYAT a'La Friedrich Karl von Savigny' (2017) 35 Jurnal Hukum \& Pembangunan 386

'Demo Hari Ini Tolak Omnibus Law: Kronologi, Daftar Lokasi, Penyebab' (tirto.id)

$<$ https://tirto.id/demo-hari-initolak-omnibus-law-kronologidaftar-lokasi-penyebab-f5Kj> accessed 26 October 2020

dkk SR, Kertas Kebijakan: Catatan Kritis Terhadap UU No. 11 Tahun 2020 Tentang Cipta Kerja (Pengesahan DPR 5 Oktober 2020) (Sri Wiyanti Eddyono ed, 2nd edn, Fakultas Hukum UGM 2020)
Fiska Maulidian, '(R)UU Omnibus Law: Dikotomi Antara Moralitas Dan Hukum' Radar Jember (Jember, 2 November 2020)

Friedrich CJ, Filsafat Hukum Perspektif Historis (Nusa Media 2008)

Gilissen J and Gorile F, Sejarah Hukum: Suatu Pengantar (Freddy Tengker tr, Kelima, PT Refika Aditama 2011)

Ibrahim A, 'Legislasi dalam Perspektif Demokrasi: Analisis Interaksi Politik dan Hukum dalam Proses Pembentukan Peraturan Daerah di Jawa Timur' (Disertasi, Universitas Diponegoro 2008)

Indra M, 'Konsepsi Kedaulatan Rakyat dalam Cita Hukum Pancasila' (2014) 1 Jurnal Selat 7

Irianto S, 'Sejarah dan Perkembangan Pemikiran Pluralisme Hukum dan Konsekuensi Metodologisnya' (2017) 33 Jurnal Hukum \& Pembangunan 485
Kurniawan
EJA,
'PLURALISME
HUKUM
DAN URGENSI
KAJIAN
SOCIO-LEGAL 
MENUJU STUDI DAN PENGEMBANGAN HUKUM YANG BERKEADILAN SOSIAL' (2012) 27 Yuridika $<$ http://e-

journal.unair.ac.id/index.php/YD

K/article/view/284> accessed 5 January 2021

Lidyana V, 'Buruh Tantang Menterimenteri Debat Publik soal Omnibus Law' (detikfinance) $<$ https://finance.detik.com/beritaekonomi-bisnis/d-5227173/buruhtantang-menteri-menteri-debatpublik-soal-omnibus-law> accessed 26 October 2020

Mahfud M, Politik Hukum Di Indonesia (Ed Revisi, Rajawali Pers 2014)

Media KC, 'Jokowi Ungkap Alasan RUU Cipta Kerja Dikebut di Tengah Pandemi Halaman all' (KOMPAS.com)

$<$ https://nasional.kompas.com/rea d/2020/10/24/21300901/jokowiungkap-alasan-ruu-cipta-kerjadikebut-di-tengah-pandemi> accessed 28 October 2020

Muntoha M, 'DEMOKRASI DAN NEGARA HUKUM' (2009) 16
JURNAL HUKUM IUS QUIA

IUSTUM 379

Nasution L, 'Sistem Hukum Pada Masyarakat Pluralis' 1 Nomor $8 \mathrm{~b}$ 'Adalah: Buletin Hukum \& Keadilah

Nurcahyo E, 'Pancasila Sebagai Volkgeist: Pedoman Penegak Hukum Dalam Mewujudkan Integritas Diri Dan Keadilan' 9 Jurnal Magister Hukum Udayana (Udayana Master Law Journal) 142

Okezone, 'Hari Ini, 2 Juta Buruh Akan Mogok Kerja Terkait Omnibus Law : Okezone Nasional' (https://nasional.okezone.com/, 6 October 2020) $<$ https://nasional.okezone.com/rea d/2020/10/06/337/2288968/hariini-2-juta-buruh-akan-mogokkerja-terkait-omnibus-law> accessed 26 October 2020

'OMNIBUS LAW RUU CILAKA: ATURAN BERWATAK KOLONIAL' (WALHI, 30 January 2020)

$<$ http://www.walhi.or.id/omnibus- 
law-ruu-cilaka-aturan-berwatak-

kolonial> accessed 5 January 2021

Persada S, 'Jokowi Respon Demo Omnibus Law, Koalisi Sipil: Pernyataan Presiden Menyesatkan' (Tempo, 11 October 2020)

<https://nasional.tempo.co/read/1

394883/jokowi-respon-demo-

omnibus-law-koalisi-sipil-

pernyataan-presiden-

menyesatkan> accessed 26

October 2020

Purbacaraka PW, 'Sekilas Tentang Analisis Teori Sejarah Hukum FK Von Savigny Terhadap Rencana Pembuatan Undang-Undang Perbankan Syariah Di Indonesia (Suatu Pendahuluan)' (2017) 36 Jurnal Hukum \& Pembangunan 499

'Sah! Jokowi Teken Omnibus Law UU

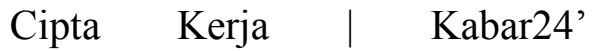
(Bisnis.com, 2 November 2020) $<$ https://kabar24.bisnis.com/read/ 20201102/15/1312668/sahjokowi-teken-omnibus-law-uucipta-kerja> accessed 20 November 2020
Setiadi W, 'Simplikasi Regulasi Dengan Menggunakan Metode Pendekatan Omnibus Law' (2020) 9 Jurnal Rechts Vinding: Media Pembinaan Hukum Nasional 39

Sibatur.com, 'UU OMNIBUS (OMNIBUS LAW), PENYEDERHANAAN

LEGISLASI, DAN KODIFIKASI ADMINISTRATIF' (Jimly School of Law and Government) $<$ https://www.jimlyschool.com/ba ca/34/uu-omnibus-omnibus-lawpenyederhanaan-legislasi-dankodifikasi-administratif $>$ accessed 4 January 2021

Simorangkir E, 'Susun Omnibus Law, Pemerintah Cuma Cabut Pasal yang Tumpang Tindih' (detikfinance)

$<$ https://finance.detik.com/beritaekonomi-bisnis/d-4868805/susunomnibus-law-pemerintah-cumacabut-pasal-yang-tumpangtindih> accessed 26 October 2020

Soekanto S, Penelitian Hukum Normatif (Raja Grafindo Persada 2009)

'Tiga Guru Besar Ini Beri Masukan Soal Omnibus Law Fakultas Hukum 
Universitas

Indonesia'

$<$ https://law.ui.ac.id/v3/tiga-guru-

besar-ini-beri-masukan-soal- omnibus-law/> accessed 4 January

2021 